AperTO - Archivio Istituzionale Open Access dell'Università di Torino

\title{
A note on the influence of Mach's psychology in The Sensory Order
}

\section{This is the author's manuscript}

Original Citation:

Availability:

This version is available http://hdl.handle.net/2318/90874

since

Publisher:

Emerald Group Publishing

Terms of use:

Open Access

Anyone can freely access the full text of works made available as "Open Access". Works made available under a Creative Commons license can be used according to the terms and conditions of said license. Use of all other works requires consent of the right holder (author or publisher) if not exempted from copyright protection by the applicable law. 


\title{
Advances in Austrian Economics \\ Emerald Book Chapter: A Note on the Influence of Mach's Psychology in the Sensory Order
}

\author{
Giandomenica Becchio
}

\section{Article information:}

To cite this document: Giandomenica Becchio, (2011),"A Note on the Influence of Mach's Psychology in the Sensory Order", Leslie Marsh, in (ed.) Hayek in Mind: Hayek's Philosophical Psychology (Advances in Austrian Economics, Volume 15), Emerald Group Publishing Limited, pp. 171 - 180

Permanent link to this document:

http://dx.doi.org/10.1108/S1529-2134(2011)0000015013

Downloaded on: 22-10-2012

References: This document contains references to 15 other documents

To copy this document: permissions@emeraldinsight.com

\section{Users who downloaded this Chapter also downloaded: *}

Jan Willem Lindemans, (2011),"Hayek's Post-Positivist Empiricism: Experience Beyond Sensation", Leslie Marsh, in (ed.) Hayek in Mind: Hayek's Philosophical Psychology (Advances in Austrian Economics, Volume 15), Emerald Group Publishing Limited, pp. 143 170

http://dx.doi.org/10.1108/S1529-2134(2011)0000015012

James R. Wible, (2011),"C. S. Peirce and F. A. Hayek on the Abstract Nature of Sensation and Cognition", Leslie Marsh, in (ed.) Hayek in Mind: Hayek's Philosophical Psychology (Advances in Austrian Economics, Volume 15), Emerald Group Publishing Limited, pp. $103-142$

http://dx.doi.org/10.1108/S1529-2134(2011)0000015011

Joshua Rust, (2011),"Hayek, Connectionism, and Scientific Naturalism", Leslie Marsh, in (ed.) Hayek in Mind: Hayek's Philosophical Psychology (Advances in Austrian Economics, Volume 15), Emerald Group Publishing Limited, pp. 29 - 50 http://dx.doi.org/10.1108/S1529-2134(2011)0000015008

Access to this document was granted through an Emerald subscription provided by Emerald Group Publishing Limited

\section{For Authors:}

If you would like to write for this, or any other Emerald publication, then please use our Emerald for Authors service. Information about how to choose which publication to write for and submission guidelines are available for all. Please visit www.emeraldinsight.com/authors for more information.

\section{About Emerald www.emeraldinsight.com}

With over forty years' experience, Emerald Group Publishing is a leading independent publisher of global research with impact in business, society, public policy and education. In total, Emerald publishes over 275 journals and more than 130 book series, as well as an extensive range of online products and services. Emerald is both COUNTER 3 and TRANSFER compliant. The organization is a partner of the Committee on Publication Ethics (COPE) and also works with Portico and the LOCKSS initiative for digital archive preservation. 


\title{
A NOTE ON THE INFLUENCE OF MACH'S PSYCHOLOGY IN THE SENSORY ORDER
}

\section{Giandomenica Becchio}

\begin{abstract}
Purpose - The aim of this note is to explain what Hayek meant when in The Sensory Order he claimed that Mach was one of his fundamental readings in psychology while he was writing The Sensory Order.

Methodology/approach - A historical approach to show the different role Mach played in Hayek and Neurath/Carnap.

Findings

- A parallelism between Mach-Kant and Hayek-Mach in psychology.

- Hayek's rejection of Mach's final philosophical approach as well as his aversion against the Vienna Circle's positivism as forms of metaphysics, based on an awkward definition of isomorphism.

Research limitations/implications

- The human sciences cannot be reduced to the natural sciences.

- Any form of knowledge is knowledge of "how" rather than of "what".
\end{abstract}

Hayek in Mind: Hayek's Philosophical Psychology

Advances in Austrian Economics, Volume 15, 171-180

Copyright (C) 2011 by Emerald Group Publishing Limited

All rights of reproduction in any form reserved

ISSN: 1529-2134/doi:10.1108/S1529-2134(2011)0000015013 
Originality/value of the paper

- To show Mach's role in Hayek's psychology.

- To consider The Sensory Order as a relevant part of Hayek's struggle against reductionism in psychology.

Keywords: Kant; Mach; Neurath; Carnap; positivism.

\section{INTRODUCTION}

In the Preface of The Sensory Order, Hayek stated that this book was based on his readings in psychology during 1919-1920, when he was still a young student in Vienna interested in both psychology and economics. Among many others, Hayek explicitly cited Mach's influence on him. Hayek's contacts with the lively Viennese milieu during the 1920s and 1930s had a fundamental role in the story of the use of Mach in Hayek's book.

As Hayek himself explained, Mach had a great influence on Viennese students and scholars until the 1930s, because he represented "the only source of arguments against a metaphysical and nebulous attitude" that was spreading among scientists (Blackmore, Itagaki, \& Tanaka, 2001, p. 124). The use of Mach's philosophy as a tool against any metaphysical attitude was particularly strong inside the Vienna Circle, where scholars like Otto Neurath and Rudolph Carnap had founded the Ernst Mach Society (Verein Ernst Mach, 1927) to support their movement and to link Mach's empiricism to their philosophical approach, which they later named "logical positivism" (Blumberg \& Feigl, 1931).

Hayek strongly criticized the Vienna Circle's philosophical approach: he mainly rejected Neurath's physicalism (the belief that all science ultimately reduces to the laws of physics, Neurath, 1931; Caldwell, 2004), even if he showed some interest in Carnap's logical system (Carnap, 1928). When Hayek introduced the system of multiple classification in The Sensory Order, he cited Carnap as the one who provided "a somewhat similar statement of the problems of the order of sensory qualities" (Hayek, 1952, p. 51). Nevertheless, in the mid-1930s, when Carnap officially subscribed to Neurath's physicalism, it culminated in the project of the unification of science (Stadler, 2001). ${ }^{1}$ Hayek's aversion arose:

From the fact that we shall never be able to achieve more than an 'explanation of the principle' by which the order of mental events is determined, it also follows that we shall never achieve a complete 'unification' of all sciences in the sense that all phenomena of which it treats can be described in physical term. (Hayek, 1952, p. 191) 
And in the following footnote he specifically named both Carnap and Neurath:

their physical language, since it refers to the phenomenal or sensory qualities of the objects, is not "physical" at all. Their use of this term rather implies a metaphysical belief in the "ultimate reality" and constancy of the phenomenal world for which there is little justification. (ibid.)

In this passage Hayek accused them of having dropped their original antimetaphysical attitude - mediated through Mach - to propose a new form a metaphysical belief, based on the reduction of any reality to the empirical realm.

Hayek's j'accuse is significant: for 30 years the philosophers of the Vienna Circle claimed Mach's philosophy as one of the main sources of their aversion to metaphysics and a pillar of their philosophical approach based on a new form of positivism. ${ }^{2}$ In the International Encyclopedia of Unified Science, Joergensen explained the three common traits between "Mach's positivism" and the Vienna Circle philosophy: the idea that "human knowledge is a biological phenomenon"; the rejection of any form of "thing-in-itself" (and for that matter, of any form of Kantianism) and the overlap between physical reality and physical elements (Joergensen, 1951, p. 853).

To explain the link between Mach and Hayek on the one hand and Hayek's aversion to the logical positivism (apparently and "officially" rooted in Mach's philosophy) on the other hand, we need to consider what Hayek meant when he mentioned Mach's influence in The Sensory Order.

\section{HAYEK'S INTERPRETATION OF MACH'S PSYCHOLOGY}

Mach discovered an interest in psychology after having read a copy of Kant's Prolegomena to Any Future Metaphysics that belonged to his father. He wrote:

The book made at the time a powerful and ineffaceable impression upon me, the like of which I never afterwards experienced in any of my philosophical reading. Some two or three years later the superfluity of the role played by "the thing in itself" abruptly dawned upon me. On a bright summer day in the open air, the world with my ego suddenly appeared to me as one coherent mass of sensations, only more strongly coherent in the ego. Although the actual working out of this thought did not occur until a later period, yet this moment was decisive for my whole view. (Blackmore, 1972, p. 30) 
Kant described the natural object of the reality not in itself (which is an impossibility), but according to the way human minds represent it through mental categories. Mach did not share Kant's conception of space and time in his Transcendental Aesthetics, but he was impressed by the way in which Kant described mental representations in his Transcendental Analytics. As it is well known, once Kant defined the process of knowledge of phenomena, as they "appear" to the human mind, he introduced the concept of Ding an sich to define not how to "know" things, but how to "think" them.

In The Sensory Order, Hayek remembered Mach's rejection of the Kantian idea of an a priori (the so-called noumenon or Ding an sich or thing-in-itself). We can say that Hayek shared the same experience as Mach: he wrote: "in an experience very similar to what which Mach himself describes with reference to Kant's concept of the Ding an sich..." (Hayek, 1952, p. vi), he was influenced by Mach, but he rejected Mach's later approach. The influence of Mach's psychology on Hayek goes beyond the parallelism between KantMach and Mach-Hayek, though. Hayek carefully read Mach's two books: Analysis of Sensations (1897) and Knowledge and Error (1905).

In the former work, Mach considered sensations as interactions between experience and pre-formed cognitive structures; these structures are able to classify the relationship among elements that form the experienced sensations (for instance a melody is not recognized when we capture its single sounds, but when we capture the relationship among them). This process is the starting point of all our perceptions that form human experience. Hence, experience requires an a priori in a way that recalls Kant's Transcendental Analytics. Contrary to Kant's philosophy however, Mach's a priori structure of any experience is itself formed by experience: human cognitive structure is itself formed through previous experience, as well as human experience is structured by it.

In Knowledge and Error, Mach explained the conceptualization process that goes beyond sensations. He rejected the idea of a spiritual capacity inherent to the organism to order sensations (in a Kantian way) and introduced what he called "higher-order thought patterns" (representations, feelings, affects, and moods) as a "summary of a recognizable "way of acting," based on "acquired patterns of response aiding adaptation and survival" (Arens, 1985, p. 155).

Mach claimed that things, corps, and material objects are nothing but connections among their elements, colors, sounds, and so on: human minds are able to use the sensory order to classify and to know objects; including even space and time. Mach's description of natural phenomena through a mental system of classification - in a framework of relational functions rather than 
causal/effect determinism - makes Ding an sich superfluous and transforms it in a sort of metaphysical residual (reformulated in a different way).

According to Mach, there's no difference between the objects of physics and the objects of psychology, just their orientation of research is different: a color can be regarded as an object of physics if it is related with the source of its light, but it can also be regarded as an object of psychology if it is related with its dependence on the retina. Mach clearly stated that sensations are not generated by corps, but corps are generated by the complexity of sensations and corps are mental symbols for those complexities of sensations. There is a complete parallelism between physical order and sensory order. Biology can bridge the gap between physics and psychology as well as explain the complexities of the direct connections among phenomena.

Hence, Mach's final approach in psychology was the isomorphism of physical and psychological realms to explain any kind of phenomenon in a scientific way with no room for any form of metaphysical residual. ${ }^{3}$ The Vienna Circle mediated it from Mach. Hayek did not accept Mach's final development of his psychology and rejected the Vienna Circle's physicalism: he "paradoxically" considered both as a new form of metaphysics, precisely based on that isomorphism.

\section{HAYEK ON ISOMORPHISM}

Isomorphism is a crucial point in Hayek's psychology. In The Sensory Order he claimed that there are physical objects (= realm of nature and physics) and phenomenological objects ( $=$ realm of mind and psychology):

psychology must start from stimuli defined in physical terms and proceed to show why and how the senses classify similar physical stimuli sometimes as alike and sometimes as different, and why different physical stimuli will sometimes appear as similar and sometimes as different. (Hayek, 1952, pp. 7-8)

The sensory qualities are known through subjective experience, and they form a self-contained system that enables the human mind to describe them only in terms of its relations to other qualities. If we try to give an explanation

we are not to move in a circle but are to succeed in explaining the relation of this system of qualities to the world of physics, the object of our explanation must be the whole complex relations which determine the order of the system of sensory (or rather of mental) qualities. (Hayek, 1952, p.37) 
He also added:

The only way in which we can break the circle in which we move ... and hope to arrive at an explanation of the processes ... is to construct a system of physical elements which is "topographically equivalent" or "isomorphous" with the system of sensory qualities. (ibid.)

Hayek was very careful to give a precise meaning of this isomorphism. He specified that it is "somewhat similar" to the use made by the Gestalt School, but without any form of ambiguity that was still present in their approach. Isomorphism is meant by Hayek in

its strict mathematical meaning of a structural correspondence between systems of related elements in which the relations connecting these elements possess the same formal properties. (Hayek, 1952, p. 38)

Contrary to the Gestalt School's approach, Hayek claimed that isomorphism describes only a similarity of structures as whole and of the position of corresponding elements within the structure, but says nothing about any other properties of the corresponding elements apart from their position in the structure. Isomorphism for Hayek is not a way to ban immaterial structures: the individual elements of the structure

are totally irrelevant for the question of whether the two structures are isomorphous; and isomorphism may not only exist between structures made of different materials but even between material and immaterial structures so long as there exist any common formal attributes of the relations which connect the elements. (Hayek, 1952, p. 39)

Hayek goes onto explain that the physical order of the external world is known by the mental or phenomenal order of sensations even if this knowledge is largely only a "knowing how" rather than "knowing what" and "the physical order differs from the phenomenal order" (ibid.).

In the last chapter of The Sensory Order Hayek specifies that:

although the theory developed here was suggested in the first instance by the psychological views which Ernst Mach has outlined in his Analysis of Sensations and elsewhere, its systematic development leads to a refutation of his and similar phenomenalist philosophies: by destroying the conception of elementary and constant sensations as ultimate constituents of the world, it restores the necessity of a belief in an objective physical world which is different from that presented to us by our sense. (Hayek, 1952, pp. 175-176)

This is the great difference between Hayek's theory of mind and Mach's final development in psychology that led him to a phenomenalist philosophy (accepted by the Vienna Circle). Hayek considered Mach's final step as a form of reductionism he never accepted in psychology or economics. 


\section{THE SENSORY ORDER AGAINST REDUCTIONISM}

As Hayek himself stated in the Preface of The Sensory Order, psychology is essentially "dealing with the problems of the methods of the social sciences ... [a] concern with the logical character of social theory" (Hayek, 1952 , p. v). From a broader perspective, Hayek's aversion to reductionism can be seen as the reverse side of the struggle for individualism he started in the late 1930s with the publication of "Economics and Knowledge" and culminated in Individualism and Economic Order (1949), which was published just few years before his decision to revise and finally publish The Sensory Order. During the early 1950s while working on The Sensory Order, Hayek composed "Within Systems and About Systems," which dealt with the possible knowledge of our mental processes and with the relationship between knowledge and the external environment. ${ }^{4}$

In the early 1930s, Hayek edited Carl Menger's Collected Works (in German): he also wrote a well-known presentation of Menger's thought and work. It was published in Economica, and it represented the introduction of Menger to the English-speaking world (Hayek, 1934). In this essay, Hayek stressed the centrality of individualism in Menger's approach when he had described how markets work and how economic agents behave when they make an economic decision. In the same period Hayek started to work on the link between economic choice and individual knowledge, which culminated in his well-known paper Economics and Knowledge. ${ }^{5}$

From Economics and Knowledge onward, Hayek introduced psychology into economics to explain the dynamics of a society in an individualistic perspective. In this view, Hayek's decision to work back on revise and publish The Sensory Order can be regarded as the final step of his research project on the nature of individual choice.

After having described the role of knowledge in individual plans and the following mechanism of the market, as well as the use of knowledge in a competition as a discovery process, Hayek described the nature of human mind. The Sensory Order can be seen as Hayek's tool to show how people know the internal and external reality, how they form their knowledge and how they can share it to make their own plans and coordinate them.

From Hayek's presentation of Menger's thought as a stronghold of individualism (1934) to the publication of The Sensory Order (1952), Hayek's work can be regarded as a tentative to investigate how society works from an individualistic point of view and how the human mind knows from an antireductionist perspective; in opposition to a new kind of holistic 
and reductionist approach, supported by the predominant position inside the Vienna Circle, mainly by Neurath and Carnap.

The role of Mach in this story is important. Both Hayek and Neurath/ Carnap considered Mach the most influential anti-metaphysical thinker. Nevertheless, Neurath/Carnap accepted Mach's reductionism in psychology as well as his final philosophical approach as a direct development of his psychology. Furthermore, the unity between physics and psychology (between physical and sensorial orders) in Mach's thought also opened the way to the Vienna Circle's ideal of a unified science (from physics to social sciences), never accepted by Hayek.

Mach's influence on Hayek is more complex, though.

Hayek started from Mach's psychological inquiry, which was influenced by Kant's research on the nature of knowledge; but, as Mach had refused the final stage of Kantism (the Dich an sich as a metaphysical residuals), Hayek refused the final stage of Machian philosophy (the isomorphism between physical and mental realm as a form of reductionism). Hayek refused Mach's destruction of "the conception of elementary and constant sensations as ultimate constituents of the world" and he restored "the necessity of a belief in an objective physical world which is different from that presented to us by our senses" (Hayek, 1952, p. 176, 8.37). In a certain sense, Hayek went back to a sort of Kantian dualism, without introducing a negative concept, like Ding an sich. Hayek wrote:

\footnotetext{
The conclusion to which our theory leads is thus that to us not only mind as a whole but also all individual mental processes must forever remain phenomena of a special kind, which. Although produced by the same principles which we know to operate in the physical world, we shall never be able fully to explain in terms of physical laws. (Hayek, 1952, p. 191)

It will derive its statements about some mental processes from its knowledge about other mental process, but it will never be able to bridge the gap between the realm of the mental and the realm of the physical. Such a verstehende psychology, which starts from our given knowledge of mental processes, will, however, never be able to explain why we must think thus and not otherwise, why we arrive at particular conclusions. (Hayek, 1952, p. 192)
}

\section{CONCLUSION}

The Sensory Order can be regarded as a part of Hayek's methodological struggle for the individualism and antireductionism he applied to economics and psychology: if the individual mental mechanisms of choice can be explained, it would be possible to show how the market works. The reference to Mach in The Sensory Order can be regarded as a part of the 
struggle that involved the rejection of any form of new or old positivism and led him back to psychology in the early 1950 s.

\section{NOTES}

1. The International Encyclopedia of Unified Science was published from 1938 to 1969 by the University of Chicago Press and edited by Neurath, Carnap, and Morris (Morris, 1960).

2. For an historical outline of Mach's influence on the Vienna Circle and later in the US after the migration of many Viennese philosophers, see Blackmore, 1972.

3. Carnap introduced isomorphism in dealing with structural relations in logics (Friedman, 2007).

4. Hayek never finished the paper, but he chose to break it into some parts, one of these was "Degrees of explanations," he published in 1955 (Caldwell, 2000), that is considered as the starting point for Hayek's research on complex systems and on his idea that complex phenomena are founded on mental patterns, and their degree of complexity in mental and social phenomena is so high that it was necessary to find a tool to describe how they work.

5. This paper was the beginning of what has been called "Hayek's transformation" (Caldwell, 1988).

\section{REFERENCES}

Arens, K. (1985). Mach's "psychology of investigation”. Journal of the History of Behavioral Sciences, 21, 151-168.

Blackmore, J. (1972). Ernst Mach: his work, life and influence. Berkeley, CA: University of California Press.

Blackmore, J., Itagaki, R., \& Tanaka, S. (Eds.). (2001). Ernst Mach's Vienna 1895-1930: Or phenomenalism as philosophy of science. Dordrecht: Kluwer.

Blumberg, A. E., \& Feigl, H. (1931). Logical positivism: A new movement in European philosophy. The Journal of Philosophy, 28, 281-296.

Caldwell, B. (1988). Hayek's transformation. History of Political Economy, 20, 513-541.

Caldwell, B. (2000). The emergence of Hayek's ideas on cultural evolution. Review of Austrian Economics, 13, 5-22.

Caldwell, B. (2004). Some reflections on F.A. Hayek's The Sensory Order. Journal of Bioeconomics, 6, 1-16.

Carnap, R. (1928). Der Logischeaufbau der Welt. Leipzig: Felix Meiner Verlag.

Friedman, M. (2007). Carnap and the Vienna circle: Rational reconstructionism refined. In R. Creath \& M. Friedman (Eds.), The Cambridge companion to Carnap. Cambridge: Cambridge University Press.

Hayek, F. (1934). Carl Menger. Economica, 4, 393-420.

Hayek, F. (1949). Individualism and economic order. London: Routledge and Kegan Paul.

Hayek, F. (1952). The sensory order. Chicago, IL: University of Chicago Press. 
Joergensen, J. (1951). The development of logical empiricism. Chicago: The University of Chiacago Press.

Mach, E. (1897). Beiträgezuranalyse der empfindungen (1984, C. M. Williams, Trans.), The analysis of sensations and the relation of the physical to the psychical. La Salle: Open Court.

Mach, E. (1905). Erktenntnis und Irrtum, Leipzig (1976, T. McCormack \& P. Foulkes, Trans.), Knowledge and error. Dordrecht: Reidel.

Morris, C. (1960). On the history of the international encyclopedia of Unified Science. Synthese, 12(4), 517-521.

Neurath, O. (1931(1983). Physicalism. In R. Cohen (Ed.), Neurath's philosophical papers (pp. 52-57). Vienna \& Dordrecht.

Stadler, F. (2001). The Vienna circle: Studies in the origins, development, and influence of logical empiricism. Wien \& New York, NY: Springer. 